\title{
Glaciological investigations in 1984 at Tasersiaq and Qapiarfiup sermia, West Greenland
}

\author{
Ole B. Olesen
}

As part of the GGU regional programme of hydropower investigations in West Greenland, glaciological and climatological investigations were continued at Tasersiaq basin (part of inventory basin SKT, G, 16, Sarfartoq-Tasersiaq), and glaciological measurements were made at Qapiarfiup sermia (inventory number 1DB10003) in 1984. At Qapiarfiup sermia measurements were originally started in March 1981 while the permanent field station at Ta sersiaq was first established in August of the same year (Olesen, 1982).

\section{Glaciological field work}

The field work in 1984 followed the lines from former years, starting with measurements of the winter accumulation on Qapiarfiup sermia using a helicopter from the nearby town Sukkertoppen. The measurements were made in late May before any melting had taken place on the glacier. Qapiarfiup sermia was visited again in early September when the summer ablation was measured. It is assumed, that very little melting takes place after this time, as the first winter snow already covers the glacier.

At 'Amitsulô' ice cap in the Tasersiaq basin, winter balance was measured in the beginning of June when a total of 22 snow pits were dug. In some places the snow melt had started before measurements were made, but in no cases had the $0^{\circ} \mathrm{C}$-horizon penetrated to the bottom of the winter snow pack. Therefore, in all pits the full water equivalent of the winter snow cover was measured.

During the field season stake readings were taken on selected profiles at irregular time intervals for the determination of transient balances. Stake positions on the easternmost part of the ice cap were determined by triangulation from fixed points on bedrock 1th July and 4th August. The position of the front of the outlet glacier nearest to the field station was determined by tape measuring to fixed points (cairns and painted marks) on bedrock.

In late August the summer melting was determined by density measurements in nine snow pits and stake readings of the whole network. In order to assess the possible depth of meltwater refreezing in the deeper part of the firn, three thermistor strings were installed at different altitudes. Temperatures were measured at six levels from one to ten metres below surface at various times during the summer. Transportation on the $165 \mathrm{~km}^{2}$ large ice cap was maintained by snow scooters operating from the permanent field station at the south-east corner of the ice cap.

\section{Hydrological field work}

As the possible outlet from the ice dammed lake 860 , which shows variable water levels, has still not been determined, two waterlevel gauges were run throughout the summer. One was installed at the lake itself and the other at the most plausible outlet of the possible 
OAPIARFIUP SERMIA
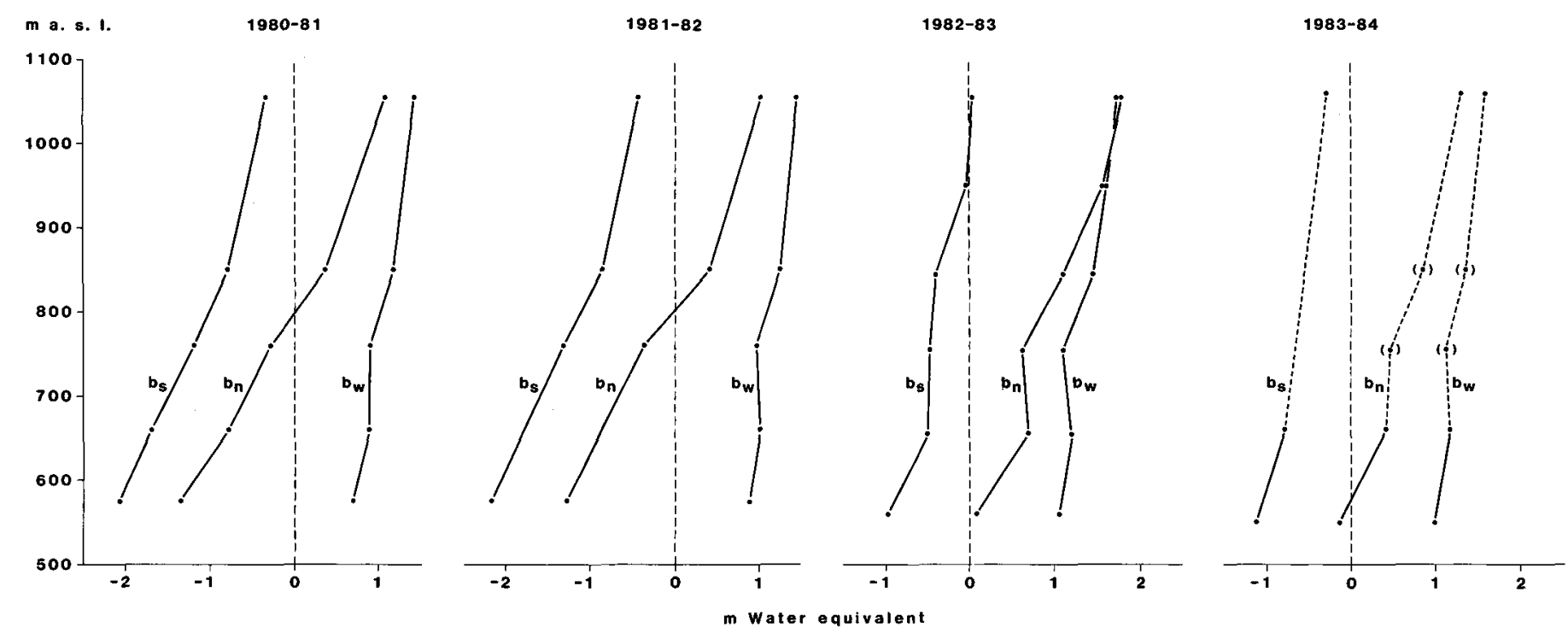

Fig. 40. Four years of mass balance from Qapiarfiup sermia. $b_{w}=$ winter balance, $b_{s}=$ summer balance, $b_{n}=$ net balance. Points in parenthesis have been calculated due to loss of stakes. 


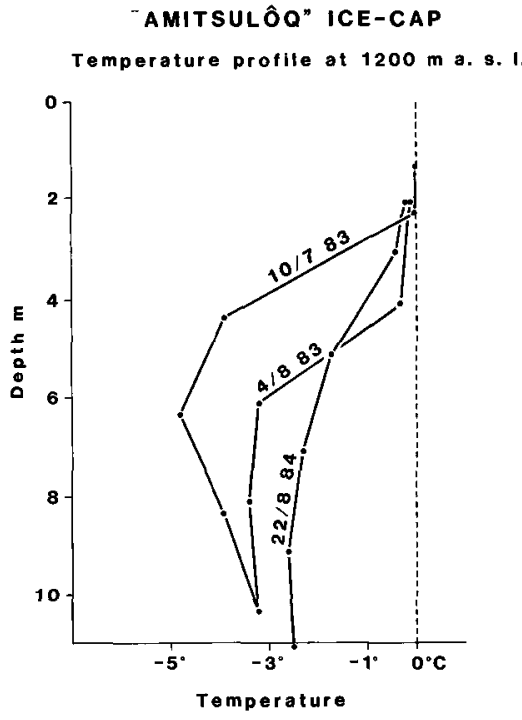

Fig. 41. Snow and firn temperatures at $1200 \mathrm{~m}$ a.s.l. from 'Amitsulôq' ice cap based on two years of measurements.

streams on the northern side of the lake. Unfortunately the ice dammed lake did not tap during the 1984 summer.

\section{Climatological measurements}

Climatological observations were made at the base camp throughout the summer, supplemented by a smaller station, with a thermohygrograph and precipitation gauge, at the same altitude on the ice cap. This year a new small station was established at $1350 \mathrm{~m}$ which appears to be well above the observed firn line. A fourth small station was operated at the westernmost end of the Tasersiaq basin i.e. halfway between base camp and the coast.

\section{Some preliminary results}

At Qapiarfiup sermia mass balance measurements started in March 1981 giving four balance years at the time of writing. Balance curves for the four years are shown in fig. 40 where

Fig. 42. Behaviour of an outlet glacier from 'Amitsulôq' ice cap based on shortest distances from four fixed points in front of the snout.

GLACIER ADVANCE

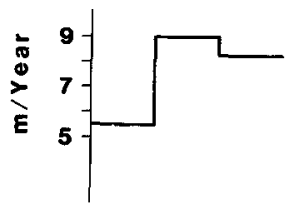

828384 Year 
points in parenthesis have been calculated due to loss of stakes during the winter. For the first two years accumulation and ablation were almost equal with the equilibrium line around $800 \mathrm{~m}$ a.s.l. while in the two following years the balance has been positive. In fact accumulation was three times the ablation in 1982/83 and double as much in 1983/84 bringing the equilibrium line down below the lower limit of the glacier (517 m a.s.l.) in 1983 and down to about $600 \mathrm{~m}$ a.s.1. in 1984. As can be seen from the curves the accumulation $\left(b_{w}\right)$ has been rather constant with a difference of only 25 per cent between the lowest in 1980-81, and the highest in 1982-83. In contrast the ablation (bs) has shown a pronounced difference of 170 per cent between the highest in 1981/82 and the lowest in 1982/83, indicating that the shift in balance stems from the large difference in summer melting.

At 'Amitsulôq' ice cap a stake net for mass balance studies was first established in the autumn of 1981 so that only three years of mass balance measurements are available. As a new map of the ice cap is in the process of being drawn (Geological Institute, Aarhus University) no hypsographic measurements have yet been carried out. The most interesting feature of the accumulation pattern is the apparent maximum between 1100 and $1200 \mathrm{~m}$. Whether this represents an actual trend in the precipitation or is due to drifting still remains to be investigated.

Although no actual mass-balances have been calculated for the 'Amitsulô' ice cap it is obvious that summer melting is the dominant factor in determining the balances and that the year-to-year trend is the same as for that of Qapiarfiup sermia. A comparison between Qapiarfiup sermia and 'Amitsulôq' shows, for the same heights, that winter accumulation is much lower at 'Amitsulôq' while summer melting is only slightly higher. This is in accord with the shift in climate conditions from Qapiarfiup sermia near the coast to 'Amitsulôq' ice cap approximately $150 \mathrm{~km}$ inland. Firn temperatures, down to $10 \mathrm{~m}$ below surface, have been measured at $1200 \mathrm{~m}$ a.s.l. in an attempt to determine depths at which meltwater refreezes. Temperature curves at different times are shown in fig. 41. It appears that at this point meltwater will refreeze within the first few metres of the firn.

The position of the outlet glacier near the base camp has been monitored for three full years and results are drawn in fig. 42 . The rate of advance appears to be proportional to the magnitude of the mass balance on a year-to-year basis.

\section{Future work}

It is expected that field work will continue at both Qapiarfiup sermia and Tasersiaq for some years. More emphasis will be placed on the distribution of firn temperatures and the refreezing of meltwater in the deeper layers of the firn.

\section{Reference}

Olesen, O. B. 1982: Establishment of a new survey station at Tasersiaq. Rapp. Grønlands geol. Unders. 110, 86-88. 